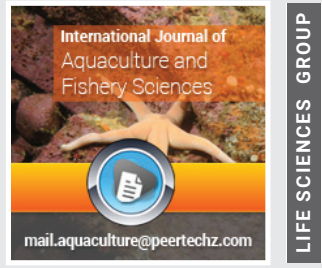

\title{
Survey on diversity, relative abundance and hydrology of fishes in Ayima, Alatish and Gelegu Rivers, of Alatish National Park, Ethiopia
}

Received: 19 December, 2020

Accepted: 17 February, 2020

Published: 18 February, 2020

*Corresponding author: Dereje Tewabe, Bahir-Dar Fisheries and Other Aquatic Life Research Center, P.O.Box 794, Bahir-Dar, Ethiopia,

E-mail: drjetewabe@yahoo.com

Keywords: Icthyofauna; Wetlands; Gill net; Fishermen; Fishing

https://www. peertechz.com

\section{Check for updates}

\section{Dereje Tewabe*}

Bahir-Dar Fisheries and Other Aquatic Life Research Center, Ethiopia

\begin{abstract}
Fish species of rivers Ayima, Alatish, and Gelegu were studied from samples collected by 6, 8, 10,12 and $14 \mathrm{~cm}$ stretched mesh size gillnet, monofilament of different mesh size, hook-lines, fykenet and castnet. The fishes were collected during October, 2008 to January, 2009. The samples were collected in the dry season and wet season. 20 fish species were identified from two rivers, but fish was not sampled from Alatish River due to its short lived seasonality, and these are included in the families Centropomidae, Cichlidae, Bagridae, Clariidae, Mochokidae, Osteoglossidae, Characidae, Citharinidae and Cyprinidae. A higher number of species was recorded from river Ayima with 20 species, whereas only two species were identified from Gelegu River. Fishing activities was destructive type, using plant poisoning materials, and chemicals (Malathion) which is non selective and dangerous for all biota.
\end{abstract}

\section{Introduction}

Ethiopia could be called a water tower of Eastern Africa in a continent where its most part is arid. The inland water body of Ethiopia is estimated at about $7,400 \mathrm{~km}^{2}$ of lake area and about 7,00okm total length of rivers [1]. These water bodies contain large population of commercially important fish species. However, the territory of Ethiopia seems to be among regions of the African continent which are least explored in icthyofauna perspectives [2].

For conservation and sustainable utilization of biological resources acquiring knowledge and developing skills and systems of conservation and proper utilization is indispensable. Strategically approaches for conservation and proper utilization process start in stocking and inventory of biological resource, inventory and assessment of root courses problems and option analysis of spatial integrity. However, assessment and conservation effort so far applied are minimal and many areas with diverse biological resources are not well known. Hence, this rapid assessment was targeted to identify hydrological issues of different rivers and icthyofauna of Alatish National park.

\section{General objective}

The major objective of the study was to generate baseline scientific information/ data about economically important and commonly found species for management and sustainable utilization of the resources, and recommend ways and means of conserving the diversity of the icthyofauna of the rivers in Alatish National park.

\section{Specific objectives}

$>$ To generate baseline data for fishing activities of the study areas.

To identify species composition of fishes in the rivers.

$>$ To evaluate the relative abundance of fish species in the rivers. 


\section{Study areas}

Gelegu town is a capital of Quara woreda in northern Gondar administrative zone in the west direction from Shinfa town at $62 \mathrm{~km}$ distance. Selferede, Dubaba and Gelegu Rivers are rivers, which are potentially rich in fish that are found across the main road from Shinfa to Gelegu town (Quara woreda). It needs further investigation of fish stocks in these rivers. For this these rapid assessment rivers in Alatish and its bordering area assessed, potential and threats identified.

One of most impressing and unique characteristics of Alatish National Park (ALNP) is its hydrological system. Alatish, Aiyma and Gelegu with many tributaries and seasonal floods from the highlands of Quara, Alefa and Chiliga woreda carry a large volume of water in wet season. This large volume of water besides about $800 \mathrm{~mm}$ annual rainfall used as major source of life support for all biological resources of the park. Water from eastern highlands as large flood in wet season compensates dry season excessive evaporation through retention of large volume of water in the flood plain of Alatish. Ayima and Gelegu rivers boarders south and north of the park respectively, while Alatish river flows through the center of the park commencing in the eastern scrublands collected from numerous streams form a wide river bed at the foot of Berenta and joins with Nigela at the middle of Alatish (Megenagna) at which maximum volume of water is discharged.

\section{Materials and methods}

Data on fishing activities at the study areas were collected based on interview of fishermen while they were fishing, processing and marketing. Data were collected in two seasons: the wet season (Just after the rainy season that means October, 2008 and the dry season that means January, 2009. Each site was sampled two times (one times in the wet season and one times in the dry season). Samples were collected using gillnets of various mesh sizes $(6 \mathrm{~cm}, 8 \mathrm{~cm}, 10 \mathrm{~cm}, 12 \mathrm{~cm}$ and $14 \mathrm{~cm}$ stretched mesh) and monofilament nets with various stretched mesh sizes (5mm-55mm stretched mesh).

An Index of Relative Importance (IRI) and Shannon diversity index $\left(\mathrm{H}^{\prime}\right)$ were used to evaluate relative abundance and species diversity of fishes, respectively. An index of relative importance (IRI) is a measure of the relative abundance or commonness of the species based on number and weight of individuals in catches, as well as their frequency of occurrence $[3,4]$. An index of relative importance (IRI) [3-6] was used to find the most important species in terms of number, weight and frequency of occurrence in the catches from the different sampling localities. IRI gives a better representation of the ecological importance of species rather than the weight, numbers or frequency of occurrence alone [7]. Index of relative importance (\% IRI) was calculated as:

$$
\% I R I i=\frac{(\% W i+\% N i) X \% F i X 100}{\sum_{j-1}^{s-1}(\% W j+\% N j) X \% F j}
$$

Where \% Wi and \%Ni is percentage weight and number of each species of total catch respectively; \%Fi is percentage frequency of occurrence of each species in total number of settings. \%Wj and \% $\mathrm{Nj}$ are percentage weight and number of total species of total catch. $\% \mathrm{Fj}$ is percentage frequency of occurrence of total species in total number of settings. $\mathrm{S}$ is total number of species.

The Shannon index of diversity $\left(\mathrm{H}^{\prime}\right)$ is a measure of the number of species weighted by their relative abundances [8]. Shannon index of diversity $\left(\mathrm{H}^{\prime}\right)$ was calculated as:

$\mathrm{H}^{\prime}=\sum$ pi ln pi

Where, pi is the proportion of individuals found in the ith species. Shannon's diversity index $\left(H^{\prime}\right)$ was used to indicate diversity at different sampling sites and/or rivers. A high value indicates high species diversity.

\section{Result and discussions}

\section{Climate}

Monthly mean maximam temperature and monthly mean minimum temperature at Metema station ranges from $30^{\circ} \mathrm{C}$ during August to $42.8{ }^{\circ} \mathrm{C}$ during April and $15.4^{\circ} \mathrm{C}$ in December to $24.1^{\circ} \mathrm{C}$ in April respectively (Figure 1). Mean monthly Rainfall at the same station ranges from $0.00 \mathrm{~mm}$ during December, January and Feburary to $252.78 \mathrm{~mm}$ August (Figure 2).

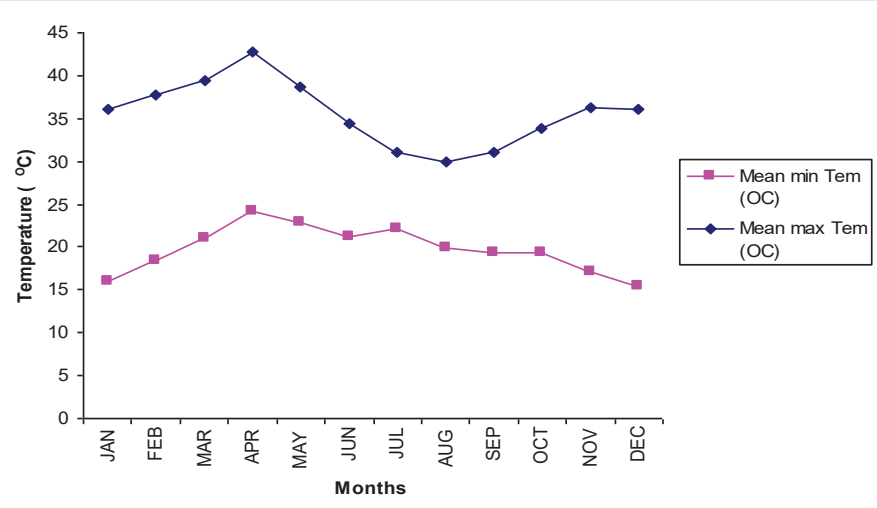

Figure 1: Monthly Mean maximum and minimum temperature at Metema station from 2004-2007, (Ethiopian Meteorological Agency, 2008).

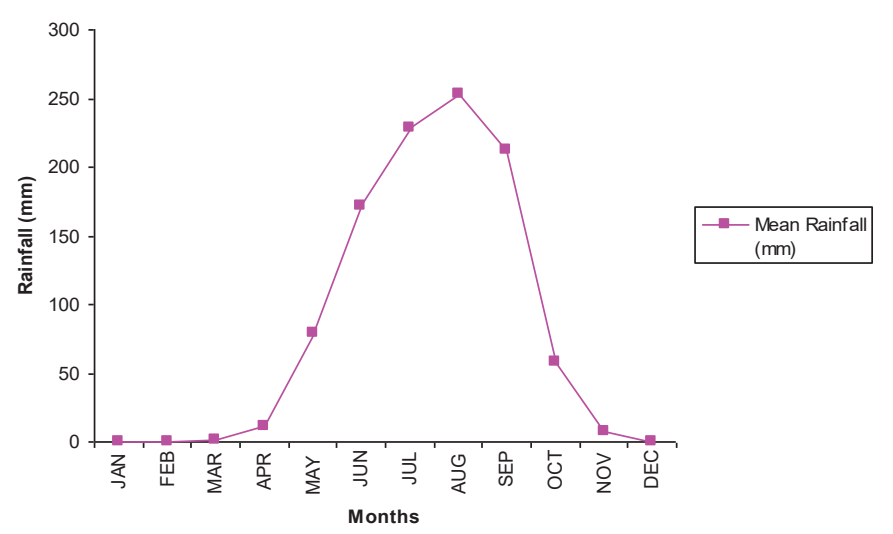

Figure 2: Mean monthly Rainfall at Metema station from 2004-2007 (Ethiopian Meteorological Agency, 2008).

Citation: Tewabe D (2020) Survey on diversity, relative abundance and hydrology of fishes in Ayima, Alatish and Gelegu Rivers, of Alatish National Park, Ethiopia. Int 


\section{Characteristics of rivers and seasonal wetlands}

All rivers have attracting seasonal character. Alatish and Gelegu sink in the golden sandy river course during dry season. Of which the name of Alatish is given by the indigenous Arabic speaking Gumuz nationalities as the water sinks in the sandy river bed no surface water is seen in dry season ("Moa Altish"). The traditional people and nomads from Sudan develop water trough digging 1 to 2 meter of sandy river bed to drink hundred thousands of their cattle and other animal sustainably in the long dry season. Hence water in Alatish and in the lower course of Gelegue flows as surface in wet season and under sandy bed in dry season which is the most striking and spectacular adjustment to minimize extreme evaporation of water in the long dry season from open pan river bed of Alatish and Gelegu Rivers.

It is natural mechanism to support biological resources and interdependence of living organisms with its surrounding physical resources which provides the meaning of complete ecosystem. While Ayima River is physically dominated by rocky bed and huge stones resistant to move by large volume of water force in wet season (May to November). Ayima River is intermittent in the long dry season leaving big ponds with in short distance. Most of ponds are hided in between big canopy trees and cave shaped huge stones which minimizes the intensity of sunlight as a result evaporation decreased.

Ayima River is rich in variety of reptile and fishes. Various types of fish and reptiles used as a main source of food and exported to Sudan on which the livelihood of indigenous Gumuz people living along Ayima River depends. Many of tributaries of Alatish, Ayima and Gelegu have numerous pools some of which may retain water under sandy bed throughout the dry season. However, detail characteristics of main rivers, their tributaries and potentials are not known.

Fishing in Ayima and the upper course of Gelegu is harvested starting from in the late wet season (September) to early wet season (June). No report on fishing in Alatish but adjacent seasonal wetlands are taped an ample amount of fish and mainly loaded to Sudan. Fishing on Gelegu is only for local consumption as an additional food source on some stagnant ponds in dry season. The native communities Gumuz living in the river banks of Ayima to the direction of Beshangul Gumuz are specialized in traditional fishing techniques could create potential hazards not only fishes but also other animals can be hunted.

Other striking hydrological system of Alatish is the presence of seasonal wetlands (Sambri) and muddy (Mezega) areas that support many life forms and major wildlife and human conflict is prevalent in the long dry season. Seasonal wetlands of Alatish are characterized by grassy patches of land devoid of woody trees with various size and shape. A thin striped Sambri covers 1-3 km length around Gelegu River in Amejalie to Alga (Figure 3). Where as circular and rectangular shaped Sumbries of a single patch comprises about 0.2 to $3 \mathrm{sq} \mathrm{km}$ and interrupted by drained soils. Sambris are used as a main source of fishing for export to Sudan in a large quantity. To provide estimated quantity, since mostly fishing is illegal and needs to assess from the middle of wet season (August) to $1 / 3$ of water is remaining (October). Fishing in Sambri is harvested only once a year because of absence of water.

In central and western part of Alatish around Sukul, Yelkuk, Amtish, along Dindir Alatish boarder in Abnun and Amdok flood plains are major areas of this land feature (Figure 4). Fishes in Sumbri are believed to be transported from rivers through the outflow of water during extensive flooding or specialized in hiding their eggs in residual moisture under soil which requires detail studies on identification and reproduction behavior of hydrological biota.

\section{Fishing in ayima river}

Ayima River is found after Gelegu town to Bemur, kebele town of Quara woreda $18 \mathrm{~km}$, again from Bemur $14 \mathrm{~km}$ after traveling on foot during wet season sampling period to reach Fetene bahir sampling site (Table 1). It is found at the boundary of Benishangul Gumuz region (Region six) and Quara woreda kebele where Agew and Gumuz ethnic groups are inhabited the area especially Gumuz groups are found just along the river sides, and they are highly engaged by fish consumption from Ayima River.

Ayima River arises from Jawi woreda, which is found in Awi zone of region three and the river crosses the country by bisecting two regions (Region three and Benishangul Gumuz,

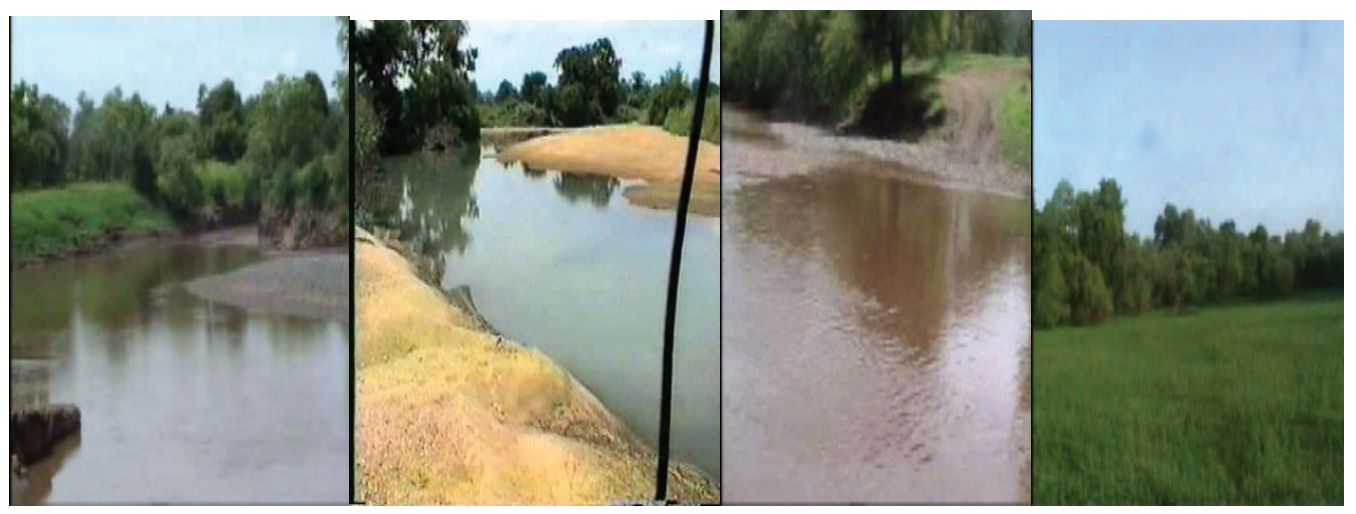

Figure 3: Hydrological resources in Alatish National park left to right Ayima, Alatish, Gelegue and Sambrin (Seasonal Wetland) during wet season.

Citation: Tewabe D (2020) Survey on diversity, relative abundance and hydrology of fishes in Ayima, Alatish and Gelegu Rivers, of Alatish National Park, Ethiopia. Int J Aquac Fish Sci 6(1): 008-014. DOI: https://dx.doi.org/10.17352/2455-8400.000050 


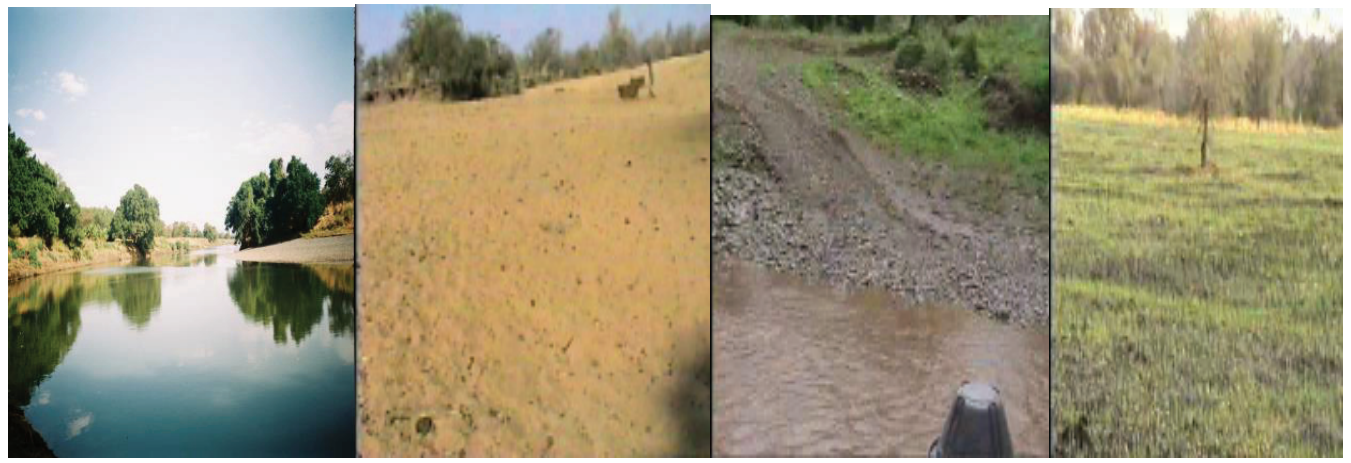

Figure 4: Major hydrological sources in Alatish, left to right Ayima, Alatish, Gelegu and Sambri which found in various patches of land during the beginning of rainy season.

Table 1: Estimated distances of sampling sites from nearby reference town, altitude and coordinates of sampling sites.

\begin{tabular}{|c|c|c|c|c|c|}
\hline River & $\begin{array}{l}\text { Sampling } \\
\text { site }\end{array}$ & $\begin{array}{c}\text { Reference } \\
\text { town }\end{array}$ & $\begin{array}{c}\text { Distance } \\
(\mathbf{k m})\end{array}$ & $\begin{array}{c}\text { Elevation } \\
\text { (a.s.l) }\end{array}$ & $\begin{array}{c}\text { Coordinate } \\
\text { (GPS) }\end{array}$ \\
\hline \multirow{2}{*}{ Ayima } & Megenagna & Gelegu & $24 \mathrm{~km}$ & 638 & $\begin{array}{l}\mathrm{N} 12^{\circ} 00^{\prime} 58.4^{\prime \prime} \\
\mathrm{E} 035^{\circ} 56^{\prime} 06.8^{\prime \prime}\end{array}$ \\
\hline & Fetene bahir & Gelegu & $32.5 \mathrm{~km}$ & 645 & $\begin{array}{l}\mathrm{N} 12^{\circ} 00^{\prime} 24.5^{\prime \prime} \\
\mathrm{E} 035^{\circ} 54^{\prime} 00.2^{\prime \prime}\end{array}$ \\
\hline
\end{tabular}

Region six). River Ayima encircles Alatish National park to Southern side and it is called Dinder River in Sudan. Major tributaries of Ayima River are Adebluk, Sid, Awjemis, Demo and Tsira Rivers. Fishery Cooperatives organized in the Ayima River is at their infant stage, there is no extension systems clearly functioning in the area regarding to fishery resource.

In Ayima River there were recently organized fishermen cooperatives organized in two teams. Each team has thirteen and sixteen members, as a result teams export dried fish to Sudan and local markets. Fishermen used materials for fishing activities by locally made gillnet and hook and lines which is bought both from Bahir dar market and Sudan (Figure 5).

Ayima River is mainly dominated by inhabitants of Gumuz and Agew ethnic groups, the immediate inhabitant to the river side is gumuz ethnic group both belongs to region six (Benishangul Gumuz) and North Gondar Zone of Quara woreda. At Ayima River especially Gumuz young groups of a society are highly experienced in fishing using spear, stones and hook and lines and used for daily consumptions both in the field and take to their home for the families (Figure 6). Fishermen are both from Gumuz, Agew and Amhara by decreasing order in proportion. Fishing is mainly conducted by gillnet fishing gear made from nylon rope made locally by bought raw materials from Sudan, but gillnets do not have both floaters and lead (Figure 5). Fishing is mainly taking place by sleeping nearby the water and collect their catch while gillnet is set at every three hour intervals this is to avoid crocodile damage and to increase the surface area of the net to trap fish (Figure 7).

In Ayima river there are two groups of fishermen organized under cooperatives, but they are not yet functional, this was due to may be inaccessibility of the area (remoteness). From Ayima River, fishermen sell their catch at Bemur town and the catch transported to Gelegu (a town of Quara Woreda) (Figure 8). Fishermen after they fish together they take to the nearby

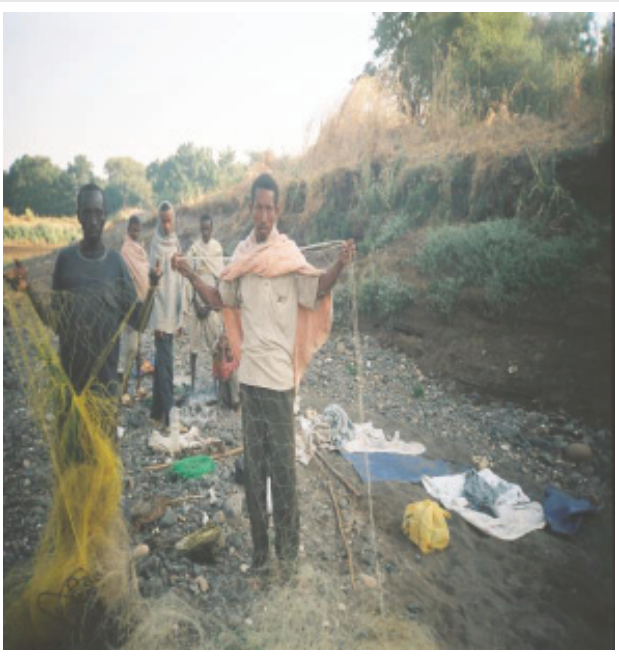

Figure 5: Local fishing gears made from Nylon rope by Gumuz and Agew tribes.

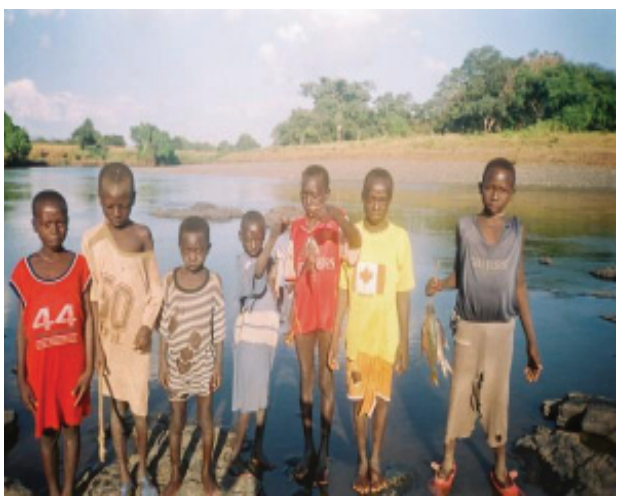

Figure 6: Children fetch fish for their daily food, and to their family at Ayima River Fishing is both with hook and lines, spear and stone.

village of individual house, who is a member of fishermen and they share their catch and take individually either for home consumption or to earn income. Gumuz individual family who live near Ayima River develope fishing system, which is permanently built during the dry season called "Guraba". Fishermen check Guraba everyday early in the morning either it has fish or not (Figure 9).

In this system of fishing fishermen can get live fish at the same time small fishes and unwanted species would be released to the river and also fishermen can take fishes to the market or 
to house consumption based on daily needs, the rest will stay for other days without spoilage, used as preservative method.

\section{Diversity and distribution of fishes}

Twenty species of fish were identified in Ayima. Because of water turbidity it was difficult to sample fishes in this field assessment from Gelegu. Other hydrological and values are assessed and Fishing in Ayima river is a vital source of both livelihood and economic sources besides its ecological and esthetic value.

Ayima river rich in variety of spices support the livelihood of indigenous people Gumuz living around it and illegal business for sale to Sudan. It requires further detail studies to identify other species in the whole course of the river and quantify the

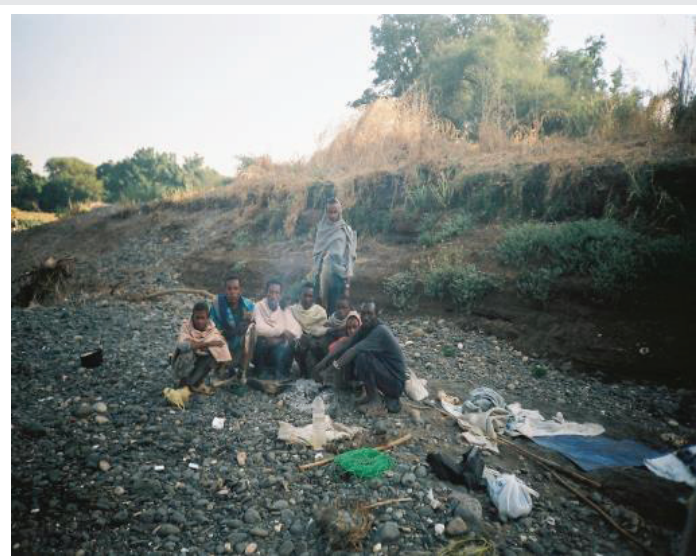

Figure 7: Fishermen sleep nearby their gillnet, keeping from crocodiles and they detach fishes every two hour interval during the night in River Ayima.

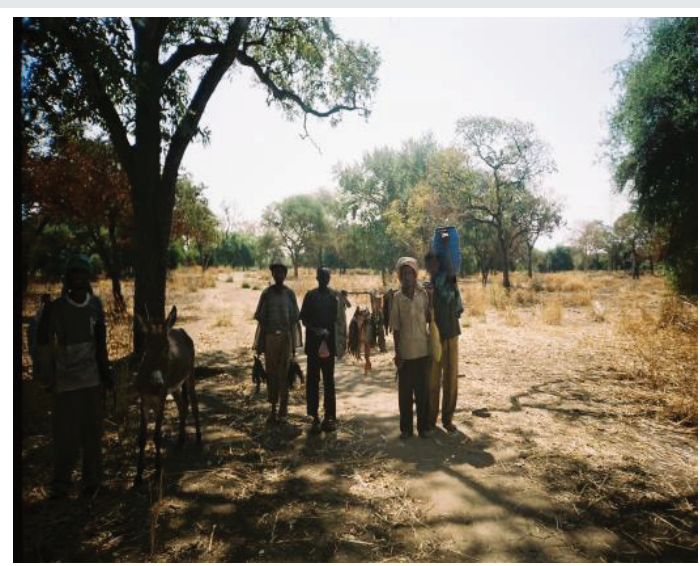

Figure 8: Ayima River fishermen selling their catch at the nearby town, Bemur.

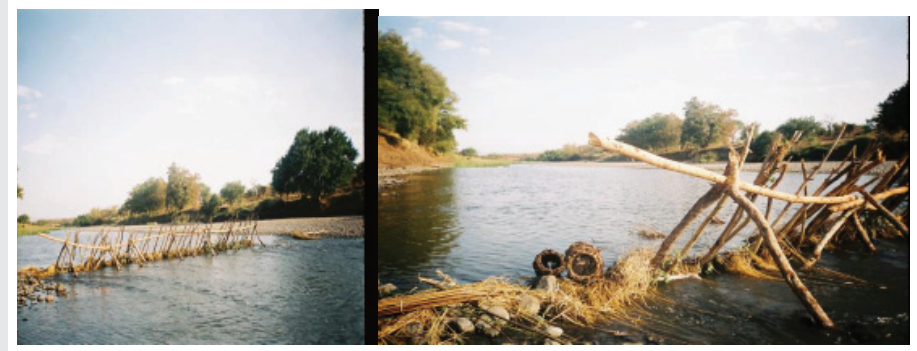

Figure 9: Type of fishing gear constructed by mainly Gumuz ethnic group, known as Guraba in Ayima River amount utilized and used for sale. However, all river courses and ponds along Abajilajil, Aybeza, Abunta, Aygumba, Kusli, Hyminishmish, balankur and Omedila are village in which fishing extensively practiced with local catching and inimical to sustainability of existing diversity. This study was only assessed to indicate diversity only in two sites at the upper course of the river Ayima around Bambaho Abajilajil and Fetene Bahir. Besides diversity of fishes in Ayima the most striking in fishing is the local knowledge of native people in fishing using various methods. There are also big pools which are not used for fishing because of their extreme depth and related with religious fears (Tikur bahir in Aybeza).

Similarly several species of fishes are expected from Gelegu River, but due to turbidity of water it was difficult to sample in both sampling periods due to unexpected rains causing flooding. Catches from the local fishermen of Gelegu River two species were identified, Clarias gariepinus and Oreochromis niloticus.

A total of 20 fish species were recorded during the present study from Ayima River (Table 2). These fishes were represented by a single class Actinopterygii (ray-finned fishes), 5 orders and 9 families (Table 2). The Siluriformes, Characiformes, and Perciformes were the best represented orders with respect to number of families; with 3, 2, and 2 families respectively and the Cyprinidae, Characidae, were the best represented families with 6 , and 4 species respectively (Table 2). Labeobarbus was the best represented genera with 4 species, (Table 2). The fish fauna of Ayima and Gelegu Rivers contain both Nilo Sudanic and highland East African, for example, L. intermedius, L. degeni, C. gariepinus and O. niloticus belong to highland East African and S. schall, S. serratus, L. forskalii, H. forskahlii and B. docmak belong to Nilo Sudanic.

\section{Species diversity during wet and dry seasons}

Species composition was much higher in the dry sampling season than in the wet sampling season. Total number of species in the catch in wet season was seventeen while it was twenty in dry season. L. forskalii, L. niloticus, L. intermedius, $L$. nedgia, H. forskalii, B. docmak, L. crassibarbis, S. serratus, S. schall, O. niloticus, L. degeni, L. bynni, B. macrolepidotus, H. longifilis, $C$. gariepinus, A. biscutatus, L. niloticus, $B$. nurse, A. baremoze, and $H$. niloticus, were found both during wet and dry seasons in total catch. C. latus was caught only during dry sampling season.

The Shannon diversity index has shows the diversity of fish species in Ayima River. The Shannon diversity index ( $\left.H^{\prime}\right)$ in Ayima River was $\left(H^{\prime}=2.86\right)$. According to Shannon's diversity index $\left(H^{\prime}\right)$ L. intermedius was the most diverse species in the total catch $\left(\mathrm{H}^{\prime}=0.272\right)$, L. forskalii was the second most diverse species in the total catch $\left(\mathrm{H}^{\prime}=0.237\right)$ and $H$. forskahlii was the third most diverse species in the total catch $\left(\mathrm{H}^{\prime}=0.203\right)$.The geomorphology of the riverine scenery in one way or another affect biodiversity pattern [9]. River width, catchments area, habitat and substrate structure such as muddy, rocky, sandy, vegetation cover of the surrounding, distance from the source, and depth have also influence on the diversity of fishes (Toham and Teugels). The discharge of water to a river seems 
influential in Ethiopian river fish diversity [10]. Therefore, the fish diversity of the studied river may be associated with rich habitat, large volume of water discharge through multiple tributaries, rich vegetation cover of catchment areas and suitable temperature. The possible factor that fish diversity was higher during dry season than wet would be high terbidity of rivers, speedy run-off, and low temperature in wet season.

\section{Relative abundance of fishes}

The species caught during all the surveys from October, 2008 to January, 2009 were ranked based on the Index of Relative Importance (IRI) (Table 3). L. intermedius, L. nedgia and L. forskalii were the most abundant species in Ayima River in order of their importance. These species have $23.9 \%$ IRI, 20.8 $\%$ IRI and $18.7 \%$ IRI, respectively (Table 3 ).

Table 2: Fish species composition of Ayima, Gelegu Rivers with their common name of Amharic and Gumuz.

\begin{tabular}{|c|c|c|c|c|c|c|}
\hline \multirow{2}{*}{ No } & \multirow{2}{*}{ Species name } & \multicolumn{2}{|c|}{ Common name } & \multirow[t]{2}{*}{ Order } & \multirow[t]{2}{*}{ Family } & \multirow[t]{2}{*}{ Genera } \\
\hline & & Amharic & Gumuz & & & \\
\hline 1 & Lates niloticus & Ayila & Burwa & Perciformes & Centropomidae & Lates \\
\hline 2 & Oreochromis niloticus & Keresso & & “ & Cichlidae & Oreochromis \\
\hline 3 & Auchenoglanis biscutatus & Lemlem Kury & Jesuma & Siluriformes & Bagridae & Auchenoglanis \\
\hline 4 & Bagrus docmak & Ambaza & Besesie & “ & " & Bagrus \\
\hline 5 & Clarias gariepinus & Bermuts & Bilbutsie & $"$ & Clariidae & Clarias \\
\hline 6 & Heterobranchus longifilis & Sorz & Bedena & “ & “ & Heterobranchus \\
\hline 7 & Synodontis serratus & Kury & Kuku & $“$ & Mochokidae & Synodontis \\
\hline 8 & Synodontis schall & “ & $“$ & " & " & “ \\
\hline 9 & Heterotis niloticus & Dulasa & Paloluha & Osteoglossiformes & Osteoglossidae & Heterotis \\
\hline 10 & Hydrocynus forskahlii & Tirso & Enza & Characiformes & Characidae & Hydrocynus \\
\hline 11 & Alestes baremoze & Beresho & Chilentie & “ & “ & Alestes \\
\hline 12 & Brycinus macrolepidotus & $\begin{array}{c}\text { Shimelo(Shimel } \\
\text { Shalia) }\end{array}$ & - & $“$ & $“$ & Brycinus \\
\hline 13 & Brycinus nurse & - & - & $“$ & $"$ & $"$ \\
\hline 14 & Citharinus latus & Sefedo & Yambda & $"$ & Citharinidae & Citharinus \\
\hline 15 & Labeo niloticus & Cuba & Mangata & Cypriniformes & Cyprinidae & Labeo \\
\hline 16 & Labeo forskalii & Tikur cuba & Tsiya & “ & “ & “ \\
\hline 17 & Labeobarbus bynni & Guanja & $"$ & $"$ & $"$ & Labeobarbus \\
\hline 18 & Labeobarbus nedgia & “ & $"$ & $"$ & $"$ & “ \\
\hline 19 & Labeobarbus degeni & “ & $“$ & $"$ & $"$ & “ \\
\hline 20 & Labeobarbus intermedius & “ & $"$ & $“$ & “ & $"$ \\
\hline
\end{tabular}

Table 3: Catch composition and Index of Relative Importance (IRI) of Ayima River.

\begin{tabular}{|c|c|c|c|c|c|c|c|c|c|c|}
\hline Species & No & $\%$ NO & $W(\mathbf{k g})$ & $\% W$ & FRQ & $\%$ FRQ & IRI & $\%$ IRI & $\mathrm{H}^{\prime}$ & $\mathbf{J}$ \\
\hline L. intermedius & 145 & 13.6 & 52.40 & 11.7 & 46 & 38.3 & 971 & 23.9 & 0.27 & 0.08 \\
\hline L. nedgia & 81 & 7.6 & 33.61 & 7.5 & 40 & 33.3 & 504 & 20.8 & 0.19 & 0.06 \\
\hline L. forskalii & 112 & 10.5 & 27.88 & 6.2 & 34 & 28.3 & 475 & 18.7 & 0.23 & 0.07 \\
\hline B. docmak & 54 & 5.1 & 42.73 & 9.5 & 37 & 30.8 & 451 & 5.5 & 0.15 & 0.05 \\
\hline H. forskahlii & 86 & 8.1 & 30.07 & 6.7 & 33 & 27.5 & 407 & 6.6 & 0.20 & 0.06 \\
\hline S. schall & 76 & 7.1 & 20.21 & 4.5 & 34 & 28.3 & 330 & 5.0 & 0.18 & 0.06 \\
\hline Labeo niloticus & 73 & 6.9 & 21.43 & 4.8 & 24 & 20.0 & 233 & 3.9 & 0.18 & 0.06 \\
\hline S. serratus & 47 & 4.4 & 19.93 & 4.4 & 30 & 25.0 & 222 & 3.7 & 0.13 & 0.04 \\
\hline L. degeni & 37 & 3.5 & 22.68 & 5.1 & 24 & 20.0 & 171 & 2.6 & 0.11 & 0.04 \\
\hline C. gariepinus & 30 & 2.8 & 39.92 & 8.9 & 16 & 13.3 & 156 & 2.3 & 0.10 & 0.03 \\
\hline O. niloticus & 44 & 4.1 & 9.22 & 2.1 & 19 & 15.8 & 98 & 2.1 & 0.13 & 0.04 \\
\hline L. bynni & 41 & 3.9 & 8.68 & 1.9 & 16 & 13.3 & 77 & 1.6 & 0.12 & 0.04 \\
\hline A. baremoze & 21 & 2.0 & 6.96 & 1.6 & 11 & 9.2 & 32 & 0.7 & 0.07 & 0.02 \\
\hline B. macrolepidotus & 24 & 2.3 & 5.91 & 1.3 & 10 & 8.3 & 30 & 0.6 & 0.08 & 0.03 \\
\hline Lates niloticus & 10 & 0.9 & 7.30 & 1.6 & 7 & 5.8 & 15 & 0.3 & 0.04 & 0.01 \\
\hline H. longifilis & 4 & 0.4 & 12.86 & 2.9 & 4 & 3.3 & 11 & 0.2 & 0.02 & 0.01 \\
\hline H. niloticus & 3 & 0.3 & 6.98 & 1.6 & 3 & 2.5 & 5 & 0.1 & 0.01 & 0.01 \\
\hline B. nurse & 10 & 0.9 & 1.43 & 0.3 & 2 & 1.7 & 2 & 0.0 & 0.04 & 0.01 \\
\hline A. biscutatus & 3 & 0.3 & 1.35 & 0.3 & 3 & 2.5 & 1 & 0.0 & 0.01 & 0.01 \\
\hline C. latus & 1 & 0.1 & & & 1 & 0.8 & 0 & 0.0 & 0.00 & 0.00 \\
\hline Total & 1063 & 100.0 & 448.17 & 100.0 & - & - & 4742 & 100.0 & 2.86 & 0.87 \\
\hline
\end{tabular}

Citation: Tewabe D (2020) Survey on diversity, relative abundance and hydrology of fishes in Ayima, Alatish and Gelegu Rivers, of Alatish National Park, Ethiopia. Int 


\section{Conclusion and recommendations}

The Siluriformes, Characiformes, and Perciformes were the best represented orders with respect to number of families; with 3, 2, and 2 families respectively and the Cyprinidae, Characidae, were the best represented families with 6 , and 4 species respectively. Labeobarbus was the best represented genera with 4 species.

Diversity and relative abundance of fishes in Gelegu and Alatish Rivers needs further investigation

Prohibited fishing gears like poisoning with Birbira (Milletia ferruginea), Lalo (Balanites egyptiaca) and the most destructive way of fishing with illegal fishing gear have to be restricted before mass destruction of fish and other living things in the water body occurs. Therefore, immediate assessment and awareness creation should be done towards this end.

Preservative methods and transporting methods for fishermen should be designed to enable them to consume and sell their catch in areas where price of fish is attractive.

Deforestation of the riparian forest will be an ultimate event by the newly settled farmers taken from most exploited areas to the virgin ones, where those rivers are found, then for cropping and livestock production activities those important flora species for the existence of fish species grown on the bank of rivers hanging over their branchs at pooled water body will be damaged, therefore, attentions should be given to conserve them.

\section{References}

1. Wood R, Talling J (1988) Chemical and algal relationships in a salinity series of Ethiopian waters. Hydrobiologia 158: 29-67. Link: http://bit.ly/2UWw5gk

2. Golubstov AS, Darkov AA, Dgebuadze Yu Y, Mina MV (1995) An Artificial key to fish species of the Gambela region (The White Nile basin in the limits of Ethiopia). Joint Ethio-Russian Biological expedition. Addis Ababa, Ethiopia. 82-84. Link: http://bit.ly/38GxnjK

3. Kolding J (1989) The fish resource of Lake Turkana and their environment Cand. Scient. Thesis, University of Bergen, Norway, 262. Link: http://bit.ly/2P2Fijv

4. Kolding J (1999) PASGEAR. A data base package for experimental or artisanal fishery data from passive gears. An introductory manual. University of Bergen Dept. of Fisheries and Marine Biology.

5. Pinkas L, Oliphant MS, Iverson ILK (1971) Food habits of albacore, blue fin tuna and bonito in Californian waters. California Fish and Game 152: 1-105. Link: http://bit.ly/2uRNagM

6. Caddy JF, Sharp GD (1986) An ecological framework of marine fishery investigations. FAO Fish. Tech. Pap. No. 283, 151. Link: http://bit.ly/323304v

7. Sanyanga RA (1996) Variation in abundance of Synodontis zambezensis (Pisces: Mockokidae) Peters 1852, in the shore fishery of Lake Kariba. Fisheries Research 26: 171-186. Link: http://bit.ly/2Hshph4

8. Begon M, HarperJL,Townsend CR (1990) Ecology: individuals, populations and communities. $2^{\text {nd }}$. Blackwell Scientific publications, 945. Link: http://bit.ly/2u9fevO

9. Wardle JV (1998) Riverine landscapes: Biodiversity patterns, disturbance regimes and aquatic conservation. Biological Conservation 83: 269-278. Link: http://bit.ly/2P2FFKV

10. Golubtsov AS, Dgebadze, Yu Y, Mina MV (2002) Fishes of the Ethiopian Rift Valley. 167-258. In: C. Tudorancea and Taylor, W.D. (eds) Ethiopian Rift Valley Lakes. Backhuys Publishers, Leiden, Holland. Link: http://bit.ly/326abJc

\section{Discover a bigger Impact and Visibility of your article publication with}

Peertechz Publications
Highlights

* Signatory publisher of ORCID

* Signatory Publisher of DORA (San Francisco Declaration on Research Assessment)

- Articles archived in worlds' renowned service providers such as Portico, CNKI, AGRIS, TDNet, Base (Bielefeld University Library), CrossRef, Scilit, J-Gate etc.

* Journals indexed in ICMJE, SHERPA/ROMEO, Google Scholar etc.

* OAI-PMH (Open Archives Initiative Protocol for Metadata Harvesting)

* Dedicated Editorial Board for every journal

Accurate and rapid peer-review process

- Increased citations of published articles through promotions

* Reduced timeline for article publication

Submit your articles and experience a new surge in publication services (https://www.peertechz.com/submission). 